Proc. Estonian Acad. Sci. Biol. Ecol., 2005, 54, 4, 347-351

\title{
The effect of potential ice nucleators on the frost survival ability of Enchytraeus variatus (Annelida, Oligochaeta)
}

\begin{abstract}
Roswitha Bauer
Department of Integrative Biology, Institute of Zoology, University of Natural Resources and Applied Life Sciences, Gregor-Mendel-Strasse 33, A-1180 Vienna, Austria; roswitha.bauer@chello.at

Received 12 October 2004, in revised form 7 June 2005

Abstract. Though enchytraeids occur in harsh climatic environments, they show only moderate eco-physiological capabilities to survive frost under laboratory conditions. Frost survival may be influenced by ice nucleators located in the gut of the worms or attached to their surface. To investigate the effect of substrate composition on the supercooling ability of Enchytraeus variatus, supercooling points (SCP) of worms and cocoons in two different culture substrates were determined. The SCPs of worms and cocoons cultured in moist nettle leaves were significantly lower than of those cultured in compost, and corresponded with the SCPs of the substrate particles in their environment.
\end{abstract}

Key words: Enchytraeidae, Enchytraeus variatus, frost survival, supercooling points, ice nucleators, cocoons.

\section{INTRODUCTION}

In laboratory experiments enchytraeids show only moderate capabilities to survive extreme cold conditions. Nevertheless, they are found in a wide variety of terrestrial habitats including Arctic, Antarctic, and Alpine soil environments. Coulson \& Birkemoe (2000) found one subadult Henlea perpusilla specimen alive in a soil sample from Svalbard that had been stored at $-22^{\circ} \mathrm{C}$ for 4 years.

Holmstrup \& Sjursen (2001) reported freeze tolerance in some specimens of Fridericia ratzeli from Greenland that were slowly cooled down to -3 and $-5^{\circ} \mathrm{C}$ in contact with moist soil. In Central Europe F. ratzeli was repeatedly observed on tree bark during winter at temperatures around $0^{\circ} \mathrm{C}$ (E. Christian, pers. comm.).

Stercutus niveus, a common and abundant species in the topsoil of deciduous forests in Central Europe during winter, is able to supercool its body fluid down to $-15^{\circ} \mathrm{C}$ (Bauer et al. 1998). The supercooling ability was significantly lower in 
individuals with filled guts than in starved animals, supporting the hypothesis that food particles may act as ice crystal nucleators (Block \& Zettel 1980). Accordingly, in the compost-dwelling species Enchytraeus variatus and E. albidus the supercooling points (SCPs) of specimens without gut contents were significantly lower $\left(-16.6 \pm 2.8^{\circ} \mathrm{C}\right.$ and $\left.-12.1 \pm 3.4^{\circ} \mathrm{C}\right)$ than the SCPs of specimens with filled guts $\left(-5.3 \pm 0.9^{\circ} \mathrm{C}\right.$ and $\left.-5.2 \pm 0.3^{\circ} \mathrm{C}\right)$ (Bauer 1998).

In undisturbed soil cores from a subalpine meadow in Austria, only enchytraeids without visible gut contents survived cooling down to -3 and $-6{ }^{\circ} \mathrm{C}$ (Bauer 2002). Experimental studies revealed a significant effect of the culture substrate (agar with nettle leaves or oats as food vs. wet filter paper without food supply) on fresh weight and SCP of Enchytraeus crypticus cocoons (Bauer et al. 2001).

To assess the influence of soil composition on the supercooling ability of E. variatus, this study compares the SCPs of worms and cocoons that were cultured in substrates with and without inorganic particles. This species was chosen for the experiments because it reproduces within a few days under laboratory conditions and a high number of cocoons were available for investigation.

\section{MATERIAL AND METHODS}

Enchytraeus variatus was cultured under laboratory conditions at room temperature $\left(22^{\circ} \mathrm{C}\right)$ in (1) dried and rewetted Urtica dioica leaves and (2) industrial compost. Household garbage was not separated and contained therefore inorganic and organic particles; it was mixed with nettle leaves as food for the worms.

The SCPs of worms, cocoons, and moist substrate particles (compost: $1 \mathrm{~mm}^{3}$; leaves: 1-2 mm diameter) were determined by attaching one sample to a vaselinecoated copper-constantan thermocouple (Bauer et al. 1998). The cooling rate was $1{ }^{\circ} \mathrm{C} \mathrm{min}^{-1}$ down to the individual freezing point. Student's $t$-test was applied for statistical evaluation.

\section{RESULTS}

The SCPs of compost-cultured E. variatus worms $(-7.1 \pm 1.3, n=20)$ and cocoons $(-7.3 \pm 1.8, n=18)$ were significantly higher $(p \leq 0.001)$ than the SCPs of the nettle-leaf cultured worms $(-11.2 \pm 3.2, n=20)$ and cocoons $(-13.7 \pm 3.1$, $n=20$ ), but lower than the SCPs of compost particles $(-4.7 \pm 0.8, n=6$;

$p \leq 0.001)$. The SCPs of nettle-leaf cultured worms and cocoons did not differ significantly from the SCPs of their substrate. The nettle-leaf SCPs ranged from -6 to $-18^{\circ} \mathrm{C}(-11.9 \pm 3.2, n=20)$.

The lowest SCP of cocoons in compost was $-12^{\circ} \mathrm{C}$, while the corresponding value for nettle-leaf cocoons was $-17^{\circ} \mathrm{C}$ (Fig. 1). In the nettle-leaf substrate, the mean SCP of cocoons was significantly lower $(p \leq 0.05)$ than the mean SCP of the worms. In the compost substrate, the mean SCPs of cocoons and worms did not differ significantly, but the former were also slightly lower. 

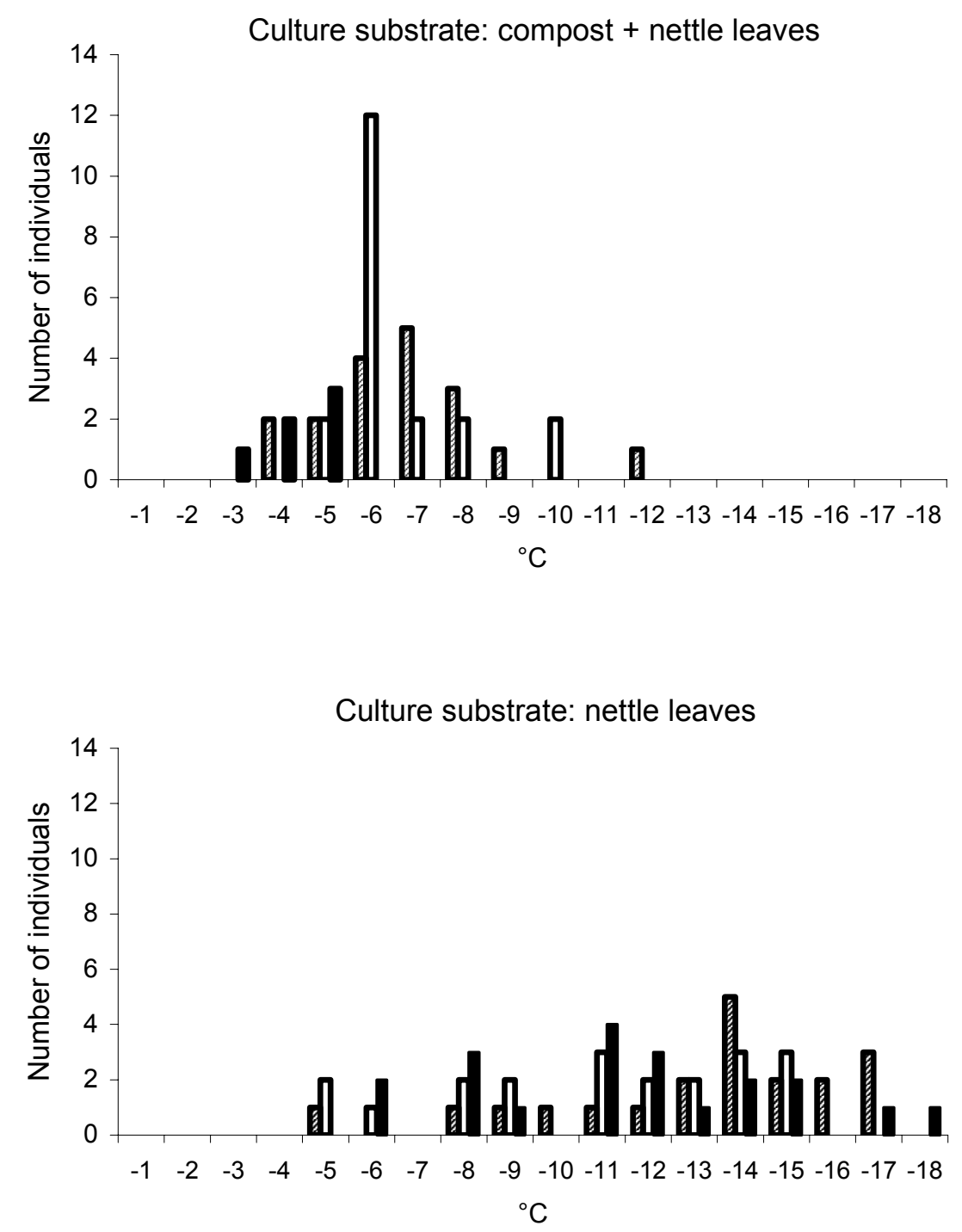

Fig. 1. Supercooling points of Enchytraeus variatus worms (white bars) and cocoons (ruled bars), and of the culture substrates (black bars).

\section{DISCUSSION}

The present study suggests a conspicuous effect of substrate composition on the supercooling ability of $E$. variatus, both in worms and cocoons. Substrate particles in the gut or attached to the body surface can induce freezing. Ice nucleating agents may be of biological origin - proteins, algae, or micro-organisms 
on decaying leaves - or inorganic, like a part of the compost particles. In freezetolerant species, ice nucleating agents induce freezing in the hemolymph at comparatively high subzero temperatures. The majority of soil animals, however, are freeze-susceptible and therefore have to avoid freezing. Most cold hardiness experiments of terrestrial invertebrates have been carried out on arthropods. Salt (1953) was the first to consider gut clearing as a way to enhance supercooling ability. In enchytraeids no active gut clearing behaviour in response to dropping temperatures was observed in an Austrian field and laboratory study (Bauer 2002). Mean SCPs of E. crypticus cocoons cultured in agar and nettle leaves were $-5.9 \pm 1.2^{\circ} \mathrm{C}$, in agar and oats $-12.7 \pm 2.5^{\circ} \mathrm{C}$, and on wet filter paper $-17.9 \pm 1.5^{\circ} \mathrm{C}$ (Bauer et al. 2001). Antifreeze agents in the food may also increase cold hardiness, as shown for the collembolan Ceratophysella sigillata (Zettel et al. 2002): compared to mixed food, algal diet decreased the SCP. Worland \& Lukešová (2000) suggested that the SCPs of mites and springtails correlate with the SCPs of their gut content.

By their moist body surface, enchytraeids are in permanent contact with the substrate they live in. Thus, eco-physiological capabilities of the worms must be considered in context with the physical and chemical properties of the surrounding substrate. Our results indicate that not only the ingested substrate particles influence the supercooling ability, but also the particles attached to the surface of the cocoons may have a considerable effect on frost survival. Cocoons of E. variatus in the two culture substrates had lower SCPs than the worms, confirming the hypothesis that enchytraeids are better protected against frost in the cocoon stage than later.

In laboratory and field studies on the eco-physiological capabilities of enchytraeids, the composition of both the gut content and the environmental substrate should be taken into account. Cold hardiness strategies of a species may change with the environmental situation, but may also be influenced by the experimental procedure, as reported by Sømme (1999). The Antarctic nematode Panagrolaimus davidi, for example, displays a freeze-avoiding strategy when cooled in air. When cooled in water, the nematodes freeze with extracellular ice formation within their body. Wharton \& Ferns (1995) showed that $P$. davidi is also able to survive even intracellular freezing.

Enchytraeids apply different cold hardiness strategies, separately or in combination: eco-physiological mechanisms such as supercooling, dehydration, and freezing tolerance, and life history responses such as starvation, migration into more favourable soil layers, and survival in the cocoon stage (Bauer 2002).

\section{ACKNOWLEDGEMENT}

I am indebted to Erhard Christian for very valuable comments on the manuscript. 


\section{REFERENCES}

Bauer, R. 1998. The effect of diet on the supercooling ability of enchytraeids (Oligochaeta). In Soil Zoological Problems in Central Europe (Pižl, V. \& Tajovský, K., eds.), pp. 9-12. České Budéjovice.

Bauer, R. 2002. Survival of frost and drought conditions in the soil by enchytraeids (Annelida; Oligochaeta) in Arctic, subalpine and temperate areas. Eur. J. Soil Biol., 38, 251-254.

Bauer, R., Kiem, R. \& Pfeffer, M. 1998. Winter survival and cold hardiness in Stercutus niveus (Oligochaeta; Enchytraeidae). Appl. Soil Ecol., 9, 87-92.

Bauer, R., Worland, M. R. \& Block, W. 2001. Experimental studies on cold survival of enchytraeid cocoons. Pedobiologia, 45, 561-571.

Block, W. \& Zettel, J. 1980. Cold hardiness of some alpine Collembola. Ecol. Entomol., 5, 1-9.

Coulson, S. J. \& Birkemoe, T. 2000. Long-term cold tolerance in arctic invertebrates: recovery after 4 years at below $-20^{\circ}$ C. Can. J. Zool., 78, 2055-2058.

Holmstrup, M. \& Sjursen, H. 2001. Freeze induced glucose accumulation in the enchytraeid, Fridericia ratzeli, from Greenland. CryoLetters, 22, 273-276.

Salt, R. W. 1953. The influence of food on cold-hardiness of insects. Can. Entomol., 85, 261-269.

Sømme, L. 1999. Cold adaptations in terrestrial invertebrates. In Cold-adapted Organisms. Ecology, Physiology, Enzymology and Molecular Biology (Margesin, R. \& Schinner, F., eds.), pp. 137-164. Springer, Berlin \& Heidelberg.

Wharton, D. A. \& Ferns, D. J. 1995. Survival of intracellular freezing by the Antarctic nematode Panagrolaimus davidi. J. Exp. Biol., 198, 1381-1387.

Worland, M. R. \& Lukešová, A. 2000. The effect of feeding on specific soil algae on the coldhardiness of two Antarctic micro-arthropods (Alaskozetes antarcticus and Cryptopygus antarcticus). Polar Biol., 23, 766-774.

Zettel, J., Zettel, U., Suter, C., Streich, S. \& Egger, B. 2002. Winter feeding behaviour of Ceratophysella sigillata (Collembola: Hypogastruridae) and the significance of eversible vesicles for resource utilisation. Pedobiologia, 46, 404-413.

\section{Potentsiaalsete jäätumistuumade mõju valgeliimuklaste (Annelida, Oligochaeta) külmakindlusele}

\section{Roswitha Bauer}

Kuigi valgeliimuklased elavad ka külmas kliimas, on nende ökofüsioloogiline külmakindlus katsetingimustes vaid mõõdukas. Külmakindlust võivad mõjutada jäätumistuumad sooles või kehapinnal. On uuritud liigi Enchytraeus variatus allajahtumisvõime sõltuvust mulla koostisest, määrates kahel eri substraadil peetud usside ja nende kookonite allajahtumispunkti. Nõgeselehtede pulbril oli nii usside kui kookonite allajahtumispunkt oluliselt madalam kui kompostil, lähedane kummagi substraadi osakeste omale. 